\title{
STRAINS OF Paraburkholderia ORIGINATED FROM RUPESTRIAN FIELDS PROMOTE THE GROWTH OF Mimosa foliolosa
}

Mariana Gonçalves Souza ${ }^{\circledR}$, Fernanda de Carvalho ${ }^{3}$ F $^{\circ}$, Silvia Maria de Oliveira-Longatti ${ }^{\circledR}$, Leonardo Paiva Barbosa $^{4}$ and Fatima Maria de Souza Moreira ${ }^{3 *}$ (C)

\footnotetext{
${ }^{1}$ Received on 21.08.2019 accepted for publication on 10.02.2020.

${ }^{2}$ Universidade Federal de Lavras, Mestrado em Engenharia Agrícola, Lavras, MG-Brasil. E-mail: <marigsouza@gmail.com>.

${ }^{3}$ Universidade Federal de Lavras, Departamento de Ciência do Solo, Lavras, MG-Brasil. E-mail:<fernandacarva@gmail.com>, <sylmarya@ yahoo.com.br> and $<$ fmoreira@ufla.br>.

${ }^{4}$ Instituto Federal Minas Gerais, Ponte Nova, MG-Brasil. E-mail: <ldpaiva@gmail.com>.

*Corresponding author.
}

\begin{abstract}
Mimosa foliolosa is a promising native species of rupestrian fields for revegetation of degraded areas in this ecosystem. The symbiosis between leguminous plants and $\mathrm{N}_{2}$-fixing bacteria may play an important role in the recovery of these areas, since these plants have better development and are more resistant to the attack of pathogens. In addition to the biological nitrogen fixation (BNF), these bacteria can promote plant growth through other processes, such as phosphate solubilization and siderophore production. We studied the cultural and genetic characteristics of 11 bacterial strains, isolated from rupestrian field soils using Mimosa tenuiflora as "trap" plant. We evaluated these strains considering their symbiotic characteristics such as nodulation, and growth-promotion of Mimosa foliolosa, as well as their ability for siderophore production and phosphate solubilization. Native N2-fixing bacterial strains belonging to the Paraburkholderia genus (UFLA01-750, UFLA01-728, UFLA01-725, and UFLA01-757), showed high symbiotic efficiency with M. foliolosa. These strains also solubilized calcium phosphate and produced siderophores, exhibiting high functional diversity and potential for use in revegetation projects.
\end{abstract}

Keywords: Nitrogen fixing bacteria; Recovery of degraded areas; Phosphate solubilization.

\section{ESTIRPES DE Paraburkholderia ORIUNDAS DE CAMPOS RUPESTRES PROMOVEM O CRESCIMENTO DE Mimosa foliolosa}

\begin{abstract}
RESUMO-Mimosa foliolosa é uma espécie nativa de campos rupestres promissora para revegetação de áreas degradadas neste ecossistema. A simbiose entre leguminosas e bactérias fixadoras de $\mathrm{N}_{2}$ pode desempenhar um papel importante na recuperação dessas áreas, uma vez que estas plantas têm melhor desenvolvimento e são mais resistentes ao ataque de patógenos. Em adição à fixação biológica de $N_{2}(-F B N)$, essas bactérias podem promover o crescimento vegetal por meio de outros processos, tais como solubilização de fosfatos e produção de sideróforos. Nós estudamos as características culturais e genéticas de 11 estirpes de bactérias isoladas de solo de campos rupestres utilizando Mimosa tenuiflora como planta isca. Nós avaliamos estas estirpes em relação as suas características simbióticas como nodulação e promoção de crescimento de Mimosa foliolosa, assim como sua habilidade de solubilizar fosfato e produzir sideróforos. Estirpes bacterianas fixadoras de $\mathrm{N}_{2}$ nativas pertencentes ao gênero Paraburkholderia (UFLA01-750, UFLA01-728, UFLA01-725 e UFLA01-757), apresentaram alta eficiência simbiótica com M. foliolosa, além de solubilizar fosfato de cálcio e produzir sideróforos, evidenciando uma alta diversidade funcional e potencial para uso em projetos de revegetação.
\end{abstract}

Palavras-Chave: Bactérias fixadoras de nitrogênio; Restauração de áreas degradadas; Solubilização de fosfato. 


\section{INTRODUCTION}

Rupestrian fields are known for the high diversity of plant and animal species that inhabit them, many of which are endemic. Given this high diversity above ground level, a large diversity of soil-dwelling organisms is expected. Studies have shown that the rupestrian fields can be considered a hotspot of diversity of an important group that composes the soil biota - the arbuscular mycorrhizal fungi (Coutinho et al., 2015; Carvalho et al., 2012).

Symbiosis between leguminous plants and Nodulating Bacteria may play an important role in processes for recovery of these areas, since these plants have better development and are more resistant to attack from pathogens (Martins et al., 2018; Ferreira et al., 2020). In addition, through improving soil fertility, they may favor the growth of other non-leguminous species (Zotarelli et al., 2012). The multifunctionality of this group of microorganisms is well-known, i.e., in addition to biological nitrogen fixation (BNF), these bacteria can promote plant growth through other processes, such as phosphate solubilization (Marra et al., 2012), which results in an increase in the supply of phosphorus available for uptake by plants, and siderophore production, which makes iron available for plant growth through the iron/siderophore bacterial complex and limits iron acquisition by plant pathogens, preventing their proliferation in this ecological niche (Neilands, 1952; Neilands, 1995). For that reason, we studied the bacterial culture and genetic characteristics of 11 native bacterial strains, among which are rhizobia and endophytic bacteria, that may have characteristics of plant growth-promoting rhizobacteria (PGPR) (Oliveira-Longatti et al., 2014). We evaluated the strains regarding their nodulation- and growth-promoting ability in Mimosa foliolosa (a leguminous plant species endemic to the rupestrian fields), as well as their ability for siderophore production and phosphate solubilization.

\section{MATERIAL AND METHODS}

The strains were isolated from nodules of Mimosa tenuiflora grown in pots containing soil from different habitats (Cerrado-tropical savanna; Peat bogs; Rocky outcrops; Quartz gravel field) of the rupestrian field ecosystem collected from the private reserve Vellozia, in the Serra do Cipó, Minas Gerais.

Soil samples from each of the 4 habitats constituted the 4 treatments that were arranged in completely randomized design with three repetitions. The experimental unit corresponded to a $1 \mathrm{~kg}$ pot with one plant per pot. Each pot contained $75 \%$ of sterile inert sandy substrate and $25 \%$ of soil from each habitat studied. Before planting Mimosa tenuiflora seeds, used as trap plant, were superficially disinfected using 70\% alcohol for $3 \mathrm{~min}, 1 \%$ sodium hypochlorite for $3 \mathrm{~min}$ and successive washing in running water. After 90 days, nodules were collected from the plants for isolation. The nodules obtained from the trap plants were first immersed in $95 \%$ ethyl alcohol for 30 seconds to break the surface tension, then immersed in $30 \%$ hydrogen peroxide for 1 to 3 minutes according to the size of the nodules. disinfect the surface of the lump, and then washed several times in sterile water. The nodules were then crushed with the aid of properly sterilized forceps in plates containing culture medium 79 (Fred and Waksman, 1928) with bromothymol blue, $\mathrm{pH}$ 6.8. The plates were incubated at $28{ }^{\circ} \mathrm{C}$. After the appearance of colonies, subculturing was performed and incubated again until obtaining isolated colonies which were described according their growth characteristics in 79 medium.

Genetic characterization of the bacterial strains was obtained by means of partial sequencing of the gene $16 \mathrm{~S}$ rRNA. The DNA of each strain was isolated using the ZR Fungal/Bacterial DNA Kit (Zymo Research Corp.). The 16S rRNA of the strains was amplified by PCR using the primer set $27 \mathrm{~F}$ (50-AGAGTTTGATCCTGGCTCAG-30) and 1492R (50-GGTTACCTTGTTACGACTT-30) (Lane, 1991). Sequences were compared to the GenBank database to obtain the most similar accessions and their similarities (Table 1). The 11 strains sequences were deposited in the GenBank under accession numbers MK649676 to MK649686.

The nodulating and plant growth-promoting ability of the strains in Mimosa foliolosa plants were evaluated in a greenhouse using seedling plug pots $\left(240 \mathrm{~cm}^{3}\right)$ containing sand and vermiculite (1:2). The experiment consisted of 15 treatments: 12 treatments involved inoculations with the 12 strains, each one inoculated separately, and irrigation with Hoagland nutrient solution (Hoagland and Arnon, 1950) containing a low concentration of mineral $\mathrm{N}\left(5.25 \mathrm{mg} \mathrm{L}^{-1}\right)$; two negative controls without inoculation, one irrigated with nutrient solution with the low concentration $\left(5.25 \mathrm{mg} \mathrm{L}^{-1}\right)$ of mineral $\mathrm{N}$ and the other with a high concentration of mineral $\mathrm{N}\left(52.5 \mathrm{mg} \mathrm{L}^{-1}\right)$; and one positive control with

Revista Árvore 2020;44:e4412 
the strain BR 3460 (Burkholderia sp.) authorized by the Brazilian Ministry of Agriculture (MAPA) as an inoculant for Mimosa bimucronata, since there is no strain authorized for $M$. foliolosa. One of the strains tested (UFLA 01-750) had already proven to be effective in $M$. bimucronata in a previous study (Araújo et al., 2017). The sources of mineral $\mathrm{N}$ used were $\mathrm{Ca}\left(\mathrm{NO}_{3}\right)_{2} \cdot 4 \mathrm{H}_{2} \mathrm{O}$, $\mathrm{KNO}_{3}$, and $\mathrm{NH}_{4} \mathrm{H}_{2} \mathrm{PO}_{4}$. The experimental design was completely randomized, with eight replications. The seedling plug pots and the nutrient solution (Hoagland and Arnon, 1950) were autoclaved for $60 \mathrm{~min}$ at a pressure of $1.5 \mathrm{~kg} \mathrm{~cm}^{2}$ at $121^{\circ} \mathrm{C}$.

Before sowing, the $M$. foliolosa seeds were disinfected and scarified, in accordance with Silveira and Fernandes (2006). After that, the seeds were pregerminated in moistened filter paper in petri-dishes for 5 days in a growth chamber at $28^{\circ} \mathrm{C}$. For each inoculated treatment, the seedlings received $1 \mathrm{~mL}$, containing $1 \times 10^{8}$ cells of the strain grown in 79 medium (Vicent, 1970).

At 70 days after setting up the experiment, the plants were collected to determine the number of nodules $(\mathrm{NN})$, nodule dry matter (NDM), shoot dry matter (SDM), root dry matter (RDM), and total dry matter (TDM). For determination of NDM, SDM, and RDM, the nodules, the shoots, and the roots were placed in paper bags and then dried in a forced air circulation oven at $60^{\circ} \mathrm{C}$ until reaching constant weight. Analysis of variance was conducted on the data from the trial using the SISVAR 5.6 statistical analysis program (Ferreira, 2011). The effects of the treatments were compared by the Scott-Knott test at 5\% probability. The NN and NDM data were transformed in square root of $\mathrm{Y}+0.5$.

The solubilization of calcium phosphate (Ca-P), aluminum phosphate (Al-P), and iron phosphate (FeP) was evaluated in solid NBRIP medium (Nautiyal, 1999), in solid GES medium (Sylvester-Bradley et al., 1982), and in solid GELP medium (Sylvester-Bradley et al., 1982), respectively. The evaluation followed the procedure described by Marra et al. (2012). Based on the solubilization index (SI), the strains were classified as having low ( $\mathrm{SI}<2 \mathrm{~mm})$, medium $(2 \mathrm{~mm} \leq \mathrm{SI}<4 \mathrm{~mm}$ ), or high ( $\mathrm{SI} \geq 4 \mathrm{~mm}$ ) solubilization capacity (Berraquero et al., 1976).

Siderophore production was evaluated in King B medium (King et al., 1954), called "poor medium" since it does not contain any source of iron. The strains were grown in liquid 79 medium for 48 hours under shaking of $100 \mathrm{rpm}$. Aliquots of $100 \mu \mathrm{L}$ of the bacterial cultures were transferred to microtubes and centrifuged $(10,000$ rpm) for 3 minutes. The supernatant was discarded and the cell mass was washed with $1.0 \mathrm{ml}$ of salt solution $(0.85 \% \mathrm{NaCl})$ three consecutive times to remove residues of the culture medium. The strains were then inoculated in King B medium and shaken at $110 \mathrm{rpm}$ for 48 hours more. After that period, $1.5 \mathrm{ml}$ of these bacterial cultures was pipetted in microtubes and centrifuged $(10,000$ rpm) for 5 minutes. Then $300 \mu \mathrm{L}$ of the supernatant was removed and added to test tubes containing $300 \mu \mathrm{L}$ of the transport solution called CAS (Alexander and Zuberer, 1991). A change from blue color to a pinkish color constituted a positive test for siderophore production. All the material used was cleaned with HCL (30\%) and running, distilled, and ultrapure water, respectively, so as not to leave any trace of contaminating material that could generate a false-positive result.

\section{RESULTS}

The origin (habitats, Global Positioning System) and Growth characteristics of twelve isolated strains are shown in Table 1.

Sequences obtained varied from 560 to $1073 \mathrm{bp}$. Most strains (7) belonged to Paraburkholderia genus with similarity to sequences in GenBank varying from $98-100 \%$. The other five strains belong to genera do not recognized as legume- nodulating bacteria, with similarities varying from 99 to $100 \%$.

The species Mimosa foliolosa nodulated with 50\% of the strains evaluated (UFLA 01-750, UFLA 01-725, UFLA 01-728, UFLA 01-757, UFLA 01-794, and UFLA 01-802); these strains belong to the Paraburkholderia genus. Among the Paraburkholderia strains identified (Table 1), UFLA 01-786 (P. nodosa) was not able to nodulate $M$. foliolosa (Table 2 ).

The strains that significantly promoted the largest number of nodules (NN) were UFLA 01-750, UFLA 01-794, and UFLA 01-802, followed by strains UFLA 01-725, UFLA 01-728, and UFLA 01-757. In regard to nodule dry matter (NDM), the highest production was obtained with strains UFLA 01-750, UFLA 01-725, and UFLA 01-794, followed by strains UFLA 01-728 and UFLA 01-757, which differed significantly from the others (Table 2). Although the strain UFLA 01-802 promoted high production of nodules, the dry matter of these nodules did not differ from the other treatments.

Revista Árvore 2020;44:e4412 


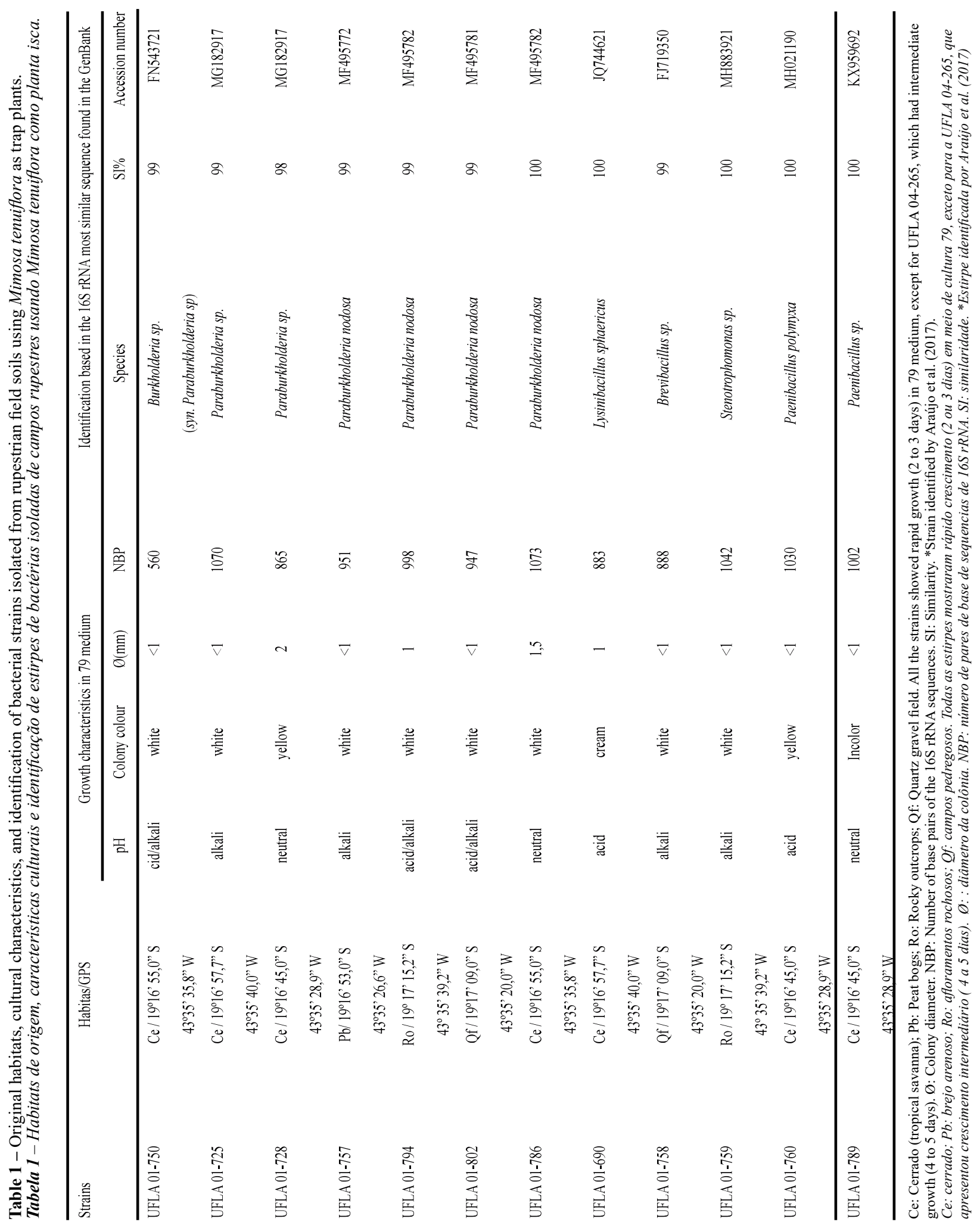




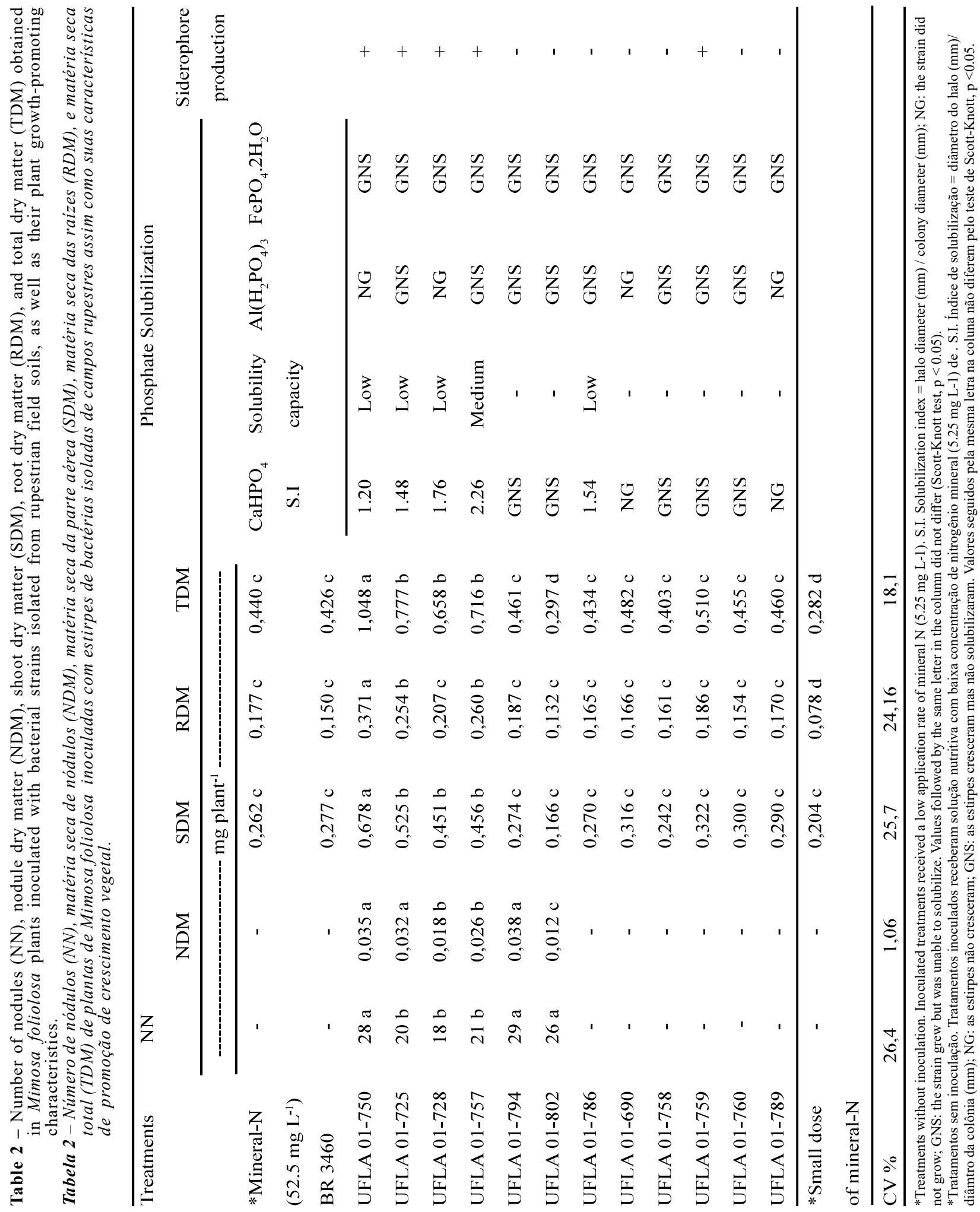


The strains UFLA 01-690, UFLA 01-758, UFLA 01-759, UFLA 01-760, and UFLA 01-789 did not form nodules in $M$. foliolosa.

The experiment to evaluate the ability of strains to promote growth of $M$. foliolosa had significant effects for all the variables analyzed. In relation to shoot dry matter, most of the strains, including two that were able to nodulate (UFLA 01-794 and UFLA 01-802), did not differ from the control with low concentration of mineral $\mathrm{N}$, which also did not differ from the control with high concentration of mineral $\mathrm{N}$, even though the control with high concentration of mineral $\mathrm{N}$ had a $28 \%$ increase in relation to the control with low concentration of mineral $\mathrm{N}$ (Table 2).

The strain UFLA 01-750 stood out not only for NN and NDM, but also for production of shoot dry matter (SDM), root dry matter (RDM), and total dry matter (TDM) (Table 2). Following that strain, three other nodule-forming strains, UFLA 01-725, UFLA 01-728, and UFLA 01-757, also led to a significant increase in production of these three parameters (Table 2).

The other root-nodule-forming strain (UFLA 01-794) and non-root-nodule-forming strains (UFLA 01-690, UFLA 01-758, UFLA 01-759, UFLA 01-760, UFLA 01-786, UFLA 01-789) also promoted growth of M. foliolosa since their production of RDM and TDM were superior to the control with low concentration of mineral N (Table 2).

In production of plant growth-promoting compounds, five strains were able to solubilize Ca-P in vitro and none was able to solubilize Fe-P and Al-P (Table 2). Nevertheless, all strains were able to grow in Fe-P and four did not grow in Al-P (Table 2). The strains that solubilized Ca-P had a low solubilization index, except for the strain UFLA 01-757, which stood out from the others since it was the only one that had medium solubilization capacity of Ca-P (Table 2).

The strains UFLA 01-750, UFLA 01-725, UFLA 01-728, and UFLA 01-757 that were able to solubilize Ca-P (Table 2) were also able to produce siderophores (Table 2) and were precisely those that led to the highest plant growth. The strain UFLA 01-786 solubilized Ca$\mathrm{P}$; however, it was not able to produce siderophores (Table 2). The strain UFLA 01-759 was able to produce siderophores; however, it did not solubilize phosphate (Table 2).

\section{DISCUSSION}

The species Mimosa foliolosa was recently recommended for ecological recovery of rupestrian fields due to its high relative growth rate and its growth in low fertility soils (Negreiros et al., 2009). In addition, symbiosis with efficient bacterial strains represents a viable strategy for preventing mortality in the initial stages of setting up environmental recovery programs (Negreiros et al., 2009). Our study shows that M. foliolosa establishes symbiosis with nitrogen fixing bacteria of the Paraburkholderia genus. Among these bacteria, the strain UFLA 01-750 had already been reported as efficient in $M$. foliolosa; however, at that time, the Paraburkholderia genus had not yet been described as including the symbiotic species of the Burkholderia genus (Dobritsa and Samadpour, 2016). Our study shows other strains of this genus also efficient in growth promotion of $M$. foliolosa and they are also able to perform other plant growth-promoting processes, such as phosphate solubilization and siderophore production. The use of species that are able to establish symbiosis with diazotrophic bacteria in recovery programs is fundamental since they have a high capacity for growth in low fertility soils and they endure severe conditions (Chaer et al., 2011), as is the case of rupestrian fields.

Therefore, we suggest that production of seedlings for setting up these programs consider inoculation of strains that are promising for promoting their development, as is the case of the strains UFLA 01-750, UFLA 01-728, UFLA 01-725, and UFLA 01-757. These nodule-forming strains that are effective in promoting the growth of $M$. foliolosa perform other processes beyond biological $\mathrm{N}_{2}$ fixation, which are important for development of seedlings and success in establishing them in the field, especially in tropical soils; because they can provide nitrogen and phosphorus directly, and iron indirectly.

In addition to nodule-forming strains, bacterial strains of other genera already reported as plantgrowth promotors (Lysinibacillus, Brevibacillus, Stenotrophomonas, and Paenibacillus) were isolated and may be also promising for the development of $M$. foliolosa seedlings . Lysinibacillus sphaericus is known for resistance to toxic metals (Velásquez and Dussán, 2009), potential for phytoremediation processes and in the growth and nutrition of plants grown in polluted soils and soils with low nutrient content (Martínez and Dussán, 2017). Brevibacillus sp. promotes plant growth

Revista Árvore 2020;44:e4412 
(increase in shoot and root dry matter), accumulation of $\mathrm{N}$ and $\mathrm{P}$, and increase in number of nodules, as well as mycorrhizal infection when co-inoculated with Rhizobium leguminosarum in Trifolium repens (Vivas et al., 2006). Some species of Stenotrophomonas can produce antimicrobial compounds that protect plants and produce ACC deaminase, gibberellic acid, indole acetic acid (IAA), and siderophores and have the capacity for solubilization of low solubility phosphates that can promote plant growth (Singh and Jha, 2017). Furthermore, many Stenotrophomonas spp. have a high level of intrinsic resistance to heavy metals and antibiotics and have shown the ability to degrade a wide range of compounds, including pollutants. For that reason, they may be used in bioremediation and phytoremediation (Ryan et al., 2009). Paenibacillus is another important genus like PGPR that can directly affect plant growth through production of indole-3-acetic acid (IAA) and other auxins and phosphate solubilization. Some species can also fix atmospheric nitrogen (Weselowski et al., 2016). As experimental conditions were adequate for expression of biological $\mathrm{N}_{2}$ fixation, i.e., there was deficiency of $\mathrm{N}$ in the mineral form, if these strains are growth promotors by other processes, growth promotion of $M$. foliolos $a$ would be manifested in a greater degree in concentrations of mineral $\mathrm{N}$ adequate for plant growth, what should be tested in further experiments. Lysinibacillus, Brevibacillus, Stenotrophomonas, and Paenibacillus are not considered as legume symbionts according to the Subcommittee on Taxonomy of Rhizobia and Agrobacteria of the International Committee on Systematics of Prokaryotes (Lajudie et al., 2019). However, they can be found as nodule endophytes on other legume species (Lima et al., 2009; Oliveira-Longatti et al., 2014).

\section{CONCLUSIONS}

The nodule-forming strains UFLA 01-750, UFLA 01-728, UFLA 01-725, and UFLA 01-757 isolated from $M$. tenuiflora originating from rupestrian field soils proved to be able to solubilize $\mathrm{Ca}-\mathrm{P}$ and produce siderophores, and were the most effective in promoting the growth of $M$. foliolosa, showing high functional diversity and potential in revegetation projects.

The $M$. foliolosa species establishes symbiosis with bacteria of the Paraburkholderia genus; however, other strains of non-nodule-forming genera, such as Paenibacillus, Brevibacillus, and Lysinibacillus, also favor M. foliolosa development.

\section{ACKOWLEDGMENTS}

We thank the Coordenação de Aperfeiçoamento de Pessoal de Nível Superior (CAPES) (CAPES/ PROEX AUXPE 593/2018), the Conselho Nacional de Desenvolvimento Científico e Tecnológico (CNPq) (Process: 304527/2016-5; Process: 431504/2016-4), and the Fundação de Amparo e Pesquisa de Minas Gerais (Fapemig) (PACCSS/PPGCS - 2009“C2012) for financial support and for granting scholarships. This research is associated with the Brazilian "Instituto Nacional de Ciência e Tecnologia - Biodiversidade do Solo" (Soil Biodiversity/INCT-CNPq).

\section{REFERENCES}

Alexander DB, Zuberer DA. Use of chrome azurol $S$ reagents to evaluate siderophore production by rhizosphere bacteria. Biology and Fertility of Soils. 1991;12(1):39-45. doi: 10.1007/BF00369386

Araújo KS, Carvalho F, Moreira FMS. Bukholderia strains promote Mimosa spp. growth but not Macroptilium atropurpureum. Revista Ciência Agronômica. 2017;48(1):41-48. doi: 10.5935/18066690.20170005

Berraquero FR, Baya AM, Cormenzana AR. Establishment of indices for the study of phosphate solubilization by soil bacteria. Ars Pharmacéutica. 1976;17:399-06. doi: 10.1590/00013765201720160111

Carvalho F, Souza FA, Carrenho R, Moreira FMS, Jesus EC, Fernandes GW. The mosaic of habitats in the high-altitude Brazilian rupestrian fields is a hotspot for arbuscular mycorrhizal fungi. Applied Soil Ecology. 2012;52:9-19. doi: 10.1016/j. apsoil.2011.10.001

Chaer GM, Resende AS, Campello EFC, Faria SM, Boddey RM. Nitrogen-fixing legume tree species for the reclamation of severely degraded lands in Brazil. Tree Physiology. 2011;31(2):139-49. doi: 10.1093/ treephys/tpq116

Coutinho ES, Fernandes GW, Berbara RLL, Valério HM, Goto BT. Variation of arbuscular mycorrhizal fungal communities along an altitudinal gradient in rupestrian grasslands in Brazil. Mycorrhiza. 2015;25(8):627-38. doi: 10.1007/s00572-015-0636-5

Dobritsa AP, Samadpour M. Transfer of eleven 
species of the genus Burkholderia to the genus Paraburkholderia and proposal of Caballeronia gen. nov. to accommodate twelve species of the genera Burkholderia and Paraburkholderia. International Journal of Systematic and Evolutionary Microbiology. 2016;66(8):2836-46. doi: 10.1099/ ijsem.0.001065

Ferreira DF. Sisvar: A computer statistical analysis system. Ciência Agrotecnologia. 2011;35(6):103942. doi: 10.1590/S1413-70542011000600001

Ferreira LVM, Carvalho F, Andrade JFC, Oliveira DP, Medeiros FHV, Moreira FMS. Co-inoculation of selected nodule endophytic rhizobacteria strains with Rhizobium tropici promotes plant growth and controls damping off in common bean. Pedosphere. 2020;30(1):98-108. doi:10.1016/S10020160(19)60825-8

Fred EB, Waksman SA. Laboratory manual of general microbiology. New York. MCGraw- Hill Book; 1928. 142 p.

Hoagland HS, Arnon DI. The water culture method for growing plants without soil. Berkeley: California Agriculture Experimental Station; 1950. 32 p.

King EO, Ward MK, Raney DE. Two simple media for the demonstration of pyocuanin and fluorescein. Journal of Laboratory and Clinical Medicine. 1954;44(2):301-7.

Lajudie PM, Andrews M, Ardley J, Eardly B, JumasBilak E, Kuzmanović N, et al. Minimal standards for the description of new genera and species of rhizobia and agrobacteria. International Journal of Systematic and Evolutionary Microbiology. 2019;69(7):185263. doi: 10.1099/ijsem.0.003426

Lane DJ. 16S/23S rRNA sequencing. In: Stackebrandt E, Goodfellow M. Nucleic acid techniques in bacterial systematics. New York, USA: Wiley; 1991. p. 115-48.

Lima AS, Nóbrega RSA, Barberi A, Silva K, Ferreira DF, Moreira FMS. Nitrogen-fixing bacteria communities occurring in soils under different uses in the Western Amazon Region as indicated by nodulation of siratro (Macroptilium atropurpureum). Plant and Soil. 2009;319:127-45. doi: 10.1007/ s11104-008-9855-2

Marra LM, Soares CRFS, Oliveira SM, Ferreira
PAA, Soares BL, Carvalho RF, et al. Biological nitrogen fixation and phosphate solubilization by bacteria isolated from tropical soils. Plant Soil. 2012;357(1-2):289-307. doi: 10.1007/s11104-012$1157-z$

Martínez SA, Dussán J. Lysinibacillus sphaericus plant growth promoter bacteria and lead phytoremediation enhancer with Canavalia ensiformis. Environmental Progress \& Sustainable Energy. 2017;37(1):276-82. doi: 10.1002/ep.12668

Martins SA, Schurt DA, Seabra SS, Martins SJ, Ramalho MAP, Moreira FMS, et al. Common bean (Phaseolus vulgaris L.) growth promotion and biocontrol by rhizobacteria under Rhizoctonia solani suppressive and conducive soils. Applied Soil Ecology. 2018;127:129-35. doi: 10.1016/j. apsoil.2018.03.007

Nautiyal CS. An efficient microbiological growth medium for screening phosphate solubilizing microorganisms. FEMS Microbiology Letters. 1999;170(1):265-70. doi:10.1111/j.1574-6968.1999. tb13383.x

Negreiros D, Fernandes GW, Silveira FAO, Chalub C. Seedling growth and biomass allocation of endemic and threatened shrubs of rupestrian fields. Acta Oecologica. 2009;35(2):301-10. doi: 10.1016/j. actao.2008.11.006

Neilands JB. A Crystalline Organo-iron Pigment from a Rust Fungus (Ustilago sphaerogena). Journal of the American Chemical Society. 1952;74(19):4846-47. doi: 10.1021/ja01139a033

Neilands JB. Siderophores: Structure and Function of Microbial Iron Transport Compounds. Journal of Biological Chemistry. 1995;270(45):26723-726. doi: 10.1074/jbc.270.45.26723

Oliveira-Longatti SM, Marra LM, Soares BL, Bomfeti CA, Silva K, Ferreira PAA, et al. Bacteria isolated from soils of the western Amazon and from rehabilitated bauxite-mining areas have potential as plant growth promoters. World Journal of Microbiology and Biotechnology. 2014;30(4):1239-50. doi: 10.1007/s11274-013$1547-2$

Ryan RP, Monchy S, Cardinale M, Taghavi S, Crossman L, Avison MB, et al. The versatility

Revista Árvore 2020;44:e4412 
and adaptation of bacteria from the genus Stenotrophomonas. Nature Reviews Microbiology. 2009;7(7):514-25. doi: 10.1038/nrmicro2163

Silveira FAO, Fernandes GW. Effect of light, temperature and scarification on the germination of Mimosa foliolosa (Leguminosae) seeds. Seed Science and Technology. 2006;34(3):585-92. doi: 10.15258/sst.2006.34.3.05

Singh RP, Jha PN. The PGPR Stenotrophomonas maltophilia SBP-9 Augments Resistance against Biotic and Abiotic Stress in Wheat Plants. Frontiers in microbiology. 2017;8:1-15. doi: 10.3389/ fmicb.2017.01945

Sylvester-Bradley R, Asakawa N, La Torraca S, Magalhães FMM, Oliveira LA, Pereira RM. Quantitative survey of phosphate solubilizing microorganisms in the rhizosphere of grasses and legumes in the Amazon. Acta Amazonica. 1982;12:15-22.

Velásquez L, Dussán J. Biosorption and bioaccumulation of heavy metals on dead and living biomass of Bacillus sphaericus. Journal of Hazardous Materials. 2009;167(1-3):713-16. doi: 10.1016/j.jhazmat.2009.01.044

Vivas A, Biró B, Ruíz-Lozano JM, Barea JM, Azcón $\mathrm{R}$. Two bacterial strains isolated from a $\mathrm{Zn}$-polluted soil enhance plant growth and mycorrhizal efficiency under Zn-toxicity. Chemosphere. 2006;62(9):152333. doi: 10.1016/j.chemosphere.2005.06.053

Weselowski B, Nathoo N, Eastman AW, MacDonald J, Yuan ZC. Isolation, identification and characterization of Paenibacillus polymyxa CR1 with potentials for biopesticide, biofertilization, biomass degradation and biofuel production. BMC Microbiology. 2016;16(1):244. doi: 10.1186/s12866-016-0860-y

Zotarelli L, Zatorre NP, Boddey RM, Urquiaga S, Jantalia CP, Franchini JC, et al. Influence of notillage and frequency of a green manure legume in crop rotations for balancing $\mathrm{N}$ outputs and preserving soil organic C stocks. Field Crops Research. 2012;132:185-95. doi: 10.1016/j.fcr.2011.12.013 